\title{
Morphological and typological assessment of architectural heritage in historical Mediterranean ports
}

\author{
A. Martino, F. Fatiguso \& G. De Tommasi \\ Department of Civil, Environmental, Territory and Building Engineering \\ and of Chemistry, Polytechnic of Bari, Italy
}

\begin{abstract}
The preservation of historical maritime heritage has become critical, due to the interference of industrial, commercial and logistic facilities, which have completely changed the maritime landscape of ports and represent a high hazard factor. In fact, anthropic activities, transformation of spaces or technological innovation produce pathological effects that, according to heritage vulnerability, lead to obsolescence and then to the damage or even to loss. The research work aims to analyse Mediterranean historical ports in order to define a methodology for risk analysis that leads to the development of strategies and guidelines for refurbishment and enhancement of architectural maritime heritage as well as for integration of the port-city system. In particular, the paper will describe and discuss the historical and morphological evolution of the most significant Mediterranean port cities. In this step of the research, the first aim is to define how the morphological structure of the ports has evolved, in relation to the historical period and the geographical position. The second is to identify and classify historical port buildings and spaces. The third is to describe the techniques for the construction of harbour works, such as piers and quays.

Keywords: historic Mediterranean ports, morphology, architectural heritage, construction techniques.
\end{abstract}

\section{Introduction}

Port cities, since the XIX ${ }^{\text {th }}$ century, have been characterized by profound changes: technological innovations in transport system, in navigation and engineering has led the port areas to renew, expand or move outside the city, changing significantly 
the relationship with the urban system. Several historical ports, aided by the movement of facilities and activities in suburb area [1,2], have been abandoned or decommissioned. In other cases, instead, ports have preserved their role, with consequent influence on the landscape, which has been profoundly changed because of the presence of industrial, logistic and commercial activities. In both cases, historical heritage of ports have been subject to pressures and negative effects producing hazard and risk factors. These factors have caused material, functional and technological obsolescence and, thus, isolation, abandonment and disuse. Because of the above-mentioned issues, preservation and enhancement of port heritage have become critical, even for its typological heterogeneity: fortress, palaces, customhouses, warehouses, arsenals, docks and piers are some examples of this heritage at risk.

Several research projects and strategies have been developed by authorities and institutions for the protection of environment and heritage of Mediterranean Sea. Among them, it is worth to mention the projects Ecoport 8 and Ten-Ecoport [3], for the promotion of a sustainable management of ports or the European project of EuroMed Heritage, which aims to protect and promote the historical values of Mediterranean countries. Furthermore, a methodology for risk assessment of the cultural heritage has been developed by Italian Central Institution of Restoration [4], subsequently implemented by the Region of Sicily in the Charter for Local Risk of waterfronts [5].

The research work has been carrying out in the $\mathrm{PhD}$ in Risk and Environmental, Territorial and Building Development at the Polytechnic of Bari, in Apulia (Italy). It aims to analyse historical ports of Mediterranean in order to define a specific methodology for risk assessment and, then, guidelines for their preservation. In this contribution, three goals will be achieved: the morphological evolution of some of most significant Mediterranean ports; identification and classification of architectural heritage of ports; the evolution of construction techniques of piers, quays and maritime works.

\section{Methodology}

In the first step, the research will discuss and describe the morphological and typological assessment of the architectural heritage of the most significant historic ports in the Mediterranean Sea. The aim is to create a knowledge framework in order to identify and classify maritime heritage and to understand the dynamics that lead to the ports transformation. The assessment methodology provides the drafting of specific analytic forms and is structured on three levels:

- Assessment of historical and morphological evolution: historical ports will be analysed in terms of typology, number, dimension and shape of basins, function, morphology and relationship with the city.

- Classification of architectural heritage: heritage will be described and classified in terms of typology, function and architecture, in relation to the geographical and historical context, in order to identify common patterns or models. 
- Assessment of the evolution of construction techniques of maritime works: they will be analysed and described the main techniques of construction of piers, quays docks over the centuries.

These three levels of analysis refer to specific categories of port cities, identified in relation of the historical context to which they refer. In fact, compared to building technologies, innovations in the naval and urban field, three main historical periods can be defined:

- Ancient Ports, until the $\mathrm{V}^{\text {th }}$ century AD.

- Medieval and Architectural Ports, between the VI ${ }^{\text {th }}$ and the XVIII ${ }^{\text {th }}$ century AD.

- Modern and Technological Ports, between the $\mathrm{XIX}^{\text {th }}$ and the $\mathrm{XX}^{\text {th }}$ century AD.

\section{Architectural heritage of Mediterranean ports}

\subsection{Ancient ports}

\subsubsection{Morphology}

In ancient times, ports were settled in natural basins or bays where ships could be repaired and replenished. The first artificial ports were built during the Roman Empire when the construction techniques of piers and quays were improved and with the introduction of new materials, such as opus cementicium and pozzolan. Therefore, it was possible to realize port infrastructure regardless of the natural conditions of the site [6]. Morphologically, two sort of ports can be identified: river ports and seaports. In the first case, ports did not have the presence of docks and piers. In fact, the linear morphology of the river allowed the construction of quays and moorings on both sides, along which port structure and infrastructure were placed, such as the river port of Ostia. Instead, piers, often fortified, quays and basins characterized seaports. Functionally, seaports had more basins, used for military or commercial functions. The inner basins could be circular, such as in Carthage, or hexagonal, as in Portus. Here, the main activities of the port took place: repair and construction of ships or loading and unloading of goods, for example. The function of outer basins, however, were mostly the shelter of ships and fleets. The commercial organization of Rome provided several ports located along coasts and rivers immediately near the city. The goods were unloaded in seaports (through naves onerariae) and then moved to Rome, for inland waterways, at the Emporium (through naves caudicariae). The main commercial seaports of Rome were Pozzuoli and Portus, the port of Claudius and Trajan, while the principal river port was Ostia. Other ports near Rome were Portus Cosanus (Ansedonia), Antium (Anzio), Centumcellae (Civitavecchia), Portus Misenum (Miseno), Torre Astura, Gravisca and Mandataria (Ventotene) [7]. The seaport of Portus, today in the archaeological site of Fiumicino, had two large curvilinear piers at the end of which was placed a monumental lighthouse. The inner basin was dug in the mainland, under Trajan. It was very similar to the cothon, characteristic basin of the Punic ports, such as the ancient Carthage [8]. The function of the cothon was mainly military, while the outer basin housed 
the commercial activities and had a rectangular form. Other important ancient ports were Leptis Magna, in Libya, and Alexandria, in Egypt.

\subsubsection{Classification of architectural heritage}

Port facilities, in ancient time, were primarily related to the commercial and military activities. The river port of Ostia has been identified as a commercial area because of the presence of archaeological remains of warehouses, called in Latin horreum [7, 9]. These buildings had a series of stores arranged side by side on the port quays, or along the piers, as in the Roman port of Cesarea Marittima [8], on the Lebanon coasts, or in the port of Leptis Magna [10]. In fact, the progress of Roman construction techniques allowed the realization of buildings on large piers. In Rome, the main warehouse was the Porticus AEmilia: the remains, nowadays

Table 1: Assessment of ancient ports up to the $\mathrm{V}^{\text {th }}$ century.

\begin{tabular}{|c|c|c|c|c|c|}
\hline Port & Basins & $\begin{array}{l}\text { Area or } \\
\text { length }\end{array}$ & $\begin{array}{c}\begin{array}{c}\text { Port } \\
\text { functions }\end{array} \\
\end{array}$ & Typology & $\begin{array}{c}\text { Port spaces and } \\
\text { buildings }\end{array}$ \\
\hline $\begin{array}{l}\text { Emporium } \\
\text { (Rome) }\end{array}$ & Fluvial & about $2 \mathrm{~km}$ & \multirow{8}{*}{ Commercial } & \multirow{11}{*}{$\begin{array}{c}\text { Port- } \\
\text { satellite of } \\
\text { the city of } \\
\text { Rome }\end{array}$} & \multirow{8}{*}{$\begin{array}{c}\text { Piers, quays } \\
\text { horrea (warehouses) } \\
\text { tabernae (workshops) } \\
\text { emporium, arcade, } \\
\text { corporations square, } \\
\text { market, fishpond, } \\
\text { tanks, aqueducts, } \\
\text { lighthouse }\end{array}$} \\
\hline Ostia & Fluvial & about $1.5 \mathrm{~km}$ & & & \\
\hline \multirow{5}{*}{$\begin{array}{c}\text { Antium } \\
\text { Torre Astura } \\
\text { Gravisca } \\
\text { Ansedonia } \\
\text { Mandataria }\end{array}$} & \multirow{5}{*}{1} & $250,000 \mathrm{~m}^{2}$ & & & \\
\hline & & $15,000 \mathrm{~m}^{2}$ & & & \\
\hline & & - & & & \\
\hline & & - & & & \\
\hline & & $11,000 \mathrm{~m}^{2}$ & & & \\
\hline Centumcellae & 2 & $150,000 \mathrm{~m}^{2}$ & & & \\
\hline Misenum & 2 & $1,000,000 \mathrm{~m}^{2}$ & Military & & $\begin{array}{c}\text { Arsenal, shipyards, } \\
\text { tanks }\end{array}$ \\
\hline Puteoli & 2 & $500,000 \mathrm{~m}^{2}$ & & & Piers, quays \\
\hline $\begin{array}{l}\text { Portus } \\
\text { Claudius } \\
\text { Trajanus }\end{array}$ & 2 & $1,500,000 \mathrm{~m}^{2}$ & $\begin{array}{c}\text { Commercial } \\
\text { Military }\end{array}$ & & $\begin{array}{l}\text { horrea - warehouses } \\
\text { tabernae - workshops } \\
\text { arcade, square, market, } \\
\text { forum, harbour office, } \\
\text { arsenal, shipyards, } \\
\text { tanks, aqueducts, } \\
\text { lighthouse, } \\
\text { fortifications, } \\
\text { inner basins, } \\
\text { imperial palace, temples }\end{array}$ \\
\hline $\begin{array}{c}\text { Cesarea } \\
\text { Maritima }\end{array}$ & 1 & $150,000 \mathrm{~m}^{2}$ & & & $\begin{array}{c}\text { Piers with horrea, } \\
\text { tabernae, fortifications, }\end{array}$ \\
\hline Alexandria & 2 & $4,000,000 \mathrm{~m}^{2}$ & & & quays, lighthouse, \\
\hline Leptis Magna & 1 & $120,000 \mathrm{~m}^{2}$ & Commercial & & $\begin{array}{l}\text { square, arcade, } \\
\text { aqueduct, }\end{array}$ \\
\hline Carthage & 2 & $150,000 \mathrm{~m}^{2}$ & Military & & $\begin{array}{l}\text { Cothon, Admiralty } \\
\text { Island, } \\
\text { fortifications, piers and } \\
\text { quays, warehouses, } \\
\text { arsenal }\end{array}$ \\
\hline
\end{tabular}


in Testaccio district, show a building made of concrete and bricks, 487 meters long and 60 meters large [11]. The warehouses of Trajan (Fig. 1), in Portus, had colonnades and corridors for the distribution of goods. They communicated with the quays, where mooring bollards and ladders for the access on ships were located [12]. Other buildings and spaces with commercial vocation were markets and squares, as the Court of Corporations, in Ostia site. Ship owners, merchants and officials traded goods in the arcaded square, with more of 60 stores around it. Ancient ports also had lighthouses, tanks, aqueducts, thermal buildings, imperial palaces, temples and fortifications [7]. Furthermore, arsenal were specific military buildings, for the construction and repair of fleets. In Carthage cothon, there was an important military building, called Admiralty Palace. Based on the reconstruction made [8] the building would have a monumental aspect, with large colonnades, stores and shipyards.

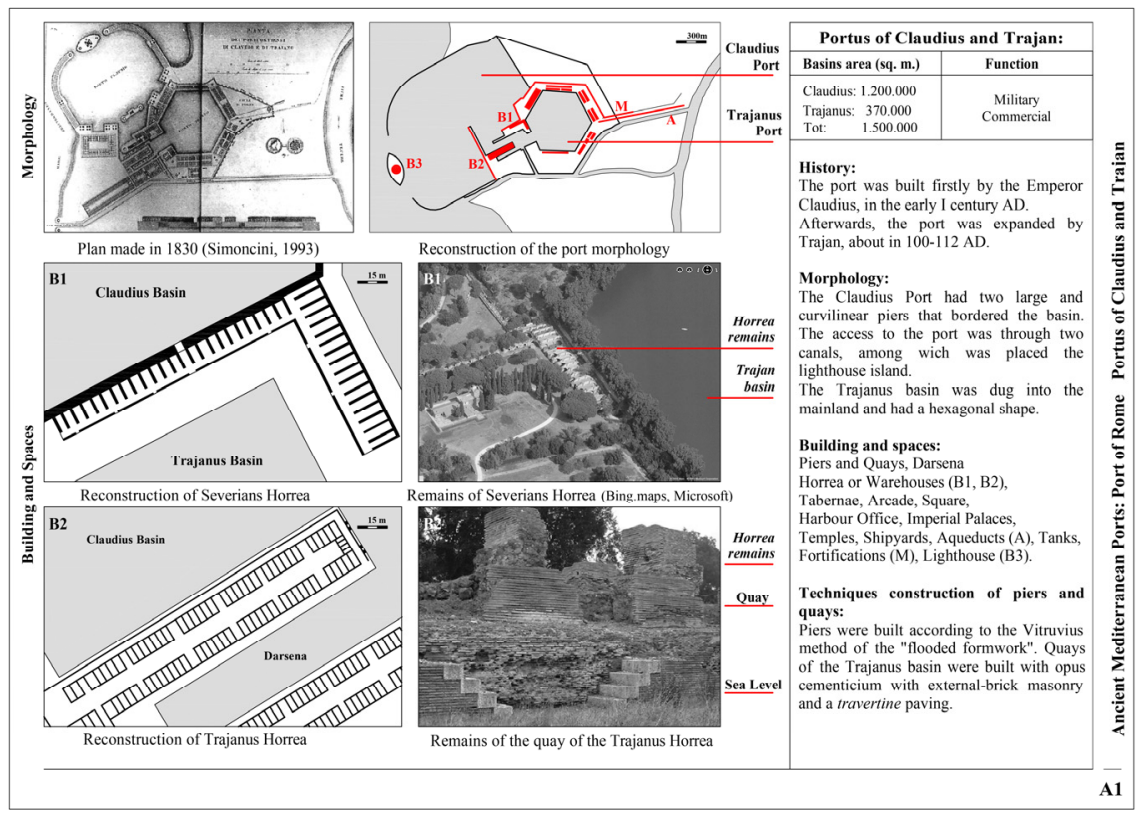

Figure 1: Assessment form, example of the Port of Claudius and Trajan.

\subsubsection{Techniques construction of piers and quays}

The main reference that can provide principles on the construction techniques of maritime works in the classical era is the De Architectura [13], by Vitruvius, dated in 27-25 BC. In the chapter "public works", he describes three techniques for the construction of piers and moles: with flooded or watertight formwork and with prefabricated blocks. The first technique involved the use of pozzolan and then could be made in water. The formwork was made of caissons (arcae) of wood planks tied (by catenae) to pales (pilae) driven into the fund. Then concrete and aggregates were thrown in that formwork. At the external side of the pier, stone 
blocks protected the structure from the waves. This technique was the most widespread, such as in the port of Antium, Portus and Cesarea Marittima [6]. When there was not pozzolan near the site, Vitruvius suggested the use of watertight formwork, from which the water was extracted. This technique is likely to have been used to build opus-pilarum piers, such as in the port of Pozzuoli [9] [14]. This typology of pier was made of pillar connected by arches. The first and second technique could both be used, in mixed piers [6]. The third method provided the use of blocks thrown in the sea, whenever it was very stormy.

\subsection{Medieval and architectural ports}

\subsubsection{Morphology}

From the Middle Ages to Renaissance, two main trends can be identified in the design of port structures and in the relationship between city and port.

Firstly, during the $\mathrm{XV}^{\text {th }}$ century, the design approach of the ports became theoretical and architectural. Architects and theorists, such as L. B. Alberti and F. di Giorgio Martini, debated on the shape of the basins, the construction techniques and the wave movement, creating various treaties and studies [15]. The models were the Roman ports. In fact, Roman port facilities were studied through the Vitruvian Treaty and direct surveys. Secondly, Mediterranean port cities were fortified because of the frequent Saracen raids on the west coasts. The centralized system of Rome and its satellite ports was replaced by isolated port cities within commercial traffics that crossed the whole Mediterranean, from East to West: the emporium cities. The model of the emporium had five characteristic elements: access roads, defensive and military architecture, commercial building and spaces. The main western ports of Mediterranean were Venice, Marseille, Genoa and Naples, who exchanged goods and products with the emporium of Acre, Istanbul, Aleppo, Damascus and Cairo, which were the last destinations of caravan routes. Between $\mathrm{IX}^{\text {th }}$ and $\mathrm{XV}^{\text {th }}$ centuries, port cities were fortified with walls, towers and bastions, both on the sea and on landside. Particularly, the ports of Barcelona, Naples and Genoa were protected by great maritime walls, as well as in the oriental emporium, massive fortifications were erected on the land front. Even the piers of the ports were fortified with high walls, leading to the displacement of the facilities towards the inner basins.

\subsubsection{Classification of architectural heritage}

The emporium-city were placed at strategic points of the Mediterranean Sea and they were closely linked. In effect, new districts of merchants arose in the port of Naples, Genoa and Venice. At the same time, Venetian and Genoese merchants resided in Acre [16], Istanbul, Damascus and other oriental port cities [17, 18]. These areas were located near the port, isolated and protected from the rest of the city. Moreover, in ports there were specific buildings and spaces used for trade. Particularly, the functions of storing and sorting of goods of the Greek aphoteke, the Byzantine mitation and the Roman horreum evolved in a new typology of port facility, used also for the rest of merchants and business negotiations. In MiddleEastern cities, they were known as karvansaray, hān o khan [19]. These architectural complexes, with oriental origins, could be urban or suburban. In the 
first case, they were placed near the port or the boundaries of the emporium city, and represented the end of a maritime or caravan traffic. The hān had a central courtyard with arcades, where merchants stopped. Around the court, on the ground floor, there were warehouses and workshops. The upper floor was destined to the merchant apartments. The strategic role of these buildings often led to their fortifications, taking it the name of Qasr, fortress widespread in Jordan, or Ribat, fortified outposts in North Africa. Other typology similar to the urban caravanserai was the funduq of the Maghreb, such as in Tripoli, Algiers, Tunis and Cairo, where it was also called wakala, dar or oukala [17]. In Italian and Andalusian ports, it is worth to mention Venetian fondacus, as the Fondacus of Germans and the Fondacus of Turks [19], built in XIII ${ }^{\text {th }}-\mathrm{XVI}^{\text {th }}$ centuries, and Corral de Carbon in Granada, formerly known as Al-funduq al-Gidida during the Arab domination. In Genoa, near the port, the presence of stationes and hospitia is witnessed by several sources. Barcelona, instead, had a grain store called Pallols, a big building used for business and trade, called Llotja, in front of the port areas [20]. In Marseille, warehouses and merchants districts were located in the lower part of the city, on the vieux port, and they were known as entrepot. During the $\mathrm{XVI}^{\text {th }}$ century, these buildings were replaced by large architectural complexes: the domaine. In these palaces merchants accumulated and deposited goods. Particle fractionation, dimension and facades were still similar to the urban fabric [21]. Other typology of port facility was the lodge, present in Naples [22] and Barcelona, among others.

These buildings were part of a complex urban area devoted to trade, known in Middle-East and North Africa as souk, suk, or suq, and in Anatolia as çarçi [17]. They were large commercial markets, with an urban dimension: narrow and vaultcovered streets, with stores and workshops, ended in centralities, such as a caravanserai or a mosque. In Istanbul, the main commercial facility was the çarçi, such as the Grand Bazar, with 20,000 square meters of architectural structures, covered streets, urban caravanserai, as the Eski Bedesten: built in the $\mathrm{XV}^{\text {th }}$ century, it could count 124 shops inside and 72 outside. The central court was covered by 15 domes, resting on 8 pillars. Urban structure similar to the oriental suq was the Ripa Maris (Fig.2), built in XII ${ }^{\text {th }}$ century in Genoa. It was a curtain of buildings placed along the waterfront, about 900 meters long. It was organized in several floors: within the maritime walls, there was a narrow walkway whit warehouses on the sides; inside the curtain, there was the "Sottoripa" portico with merchant shops; on the upper floors, there were the apartment of merchants and nobles [17].

Ports also had a military function during this historical period. The major port cities built their fleets in shipyards and arsenals, known as arsana in Venice [23], atarazanas and reial drassanes in Barcelona, tercenaux or arsenaux des galares in Marseille. Arsenals were organized in one or more basins, for ship rest and repair. The Venetian Arsenal was built in the early XIII ${ }^{\text {th }}$ century and expanded later in the XV ${ }^{\text {th }}$. It could count of three docks: Canal of Old Arsenal (1206-1224), Novo Arsenal (1300-1450) and Novissima Grande Arsenal (1470-1510). Warehouses, called magazzeni or squeri, were built for the construction and repair of ships, which were also prepared for shipping, with weaponry and crews. Arsenals factories were organized according to the function and activity. 


\subsubsection{Techniques construction of piers and quays}

Roman construction techniques remained the current practice for centuries. Particularly, the study of ports and maritime facilities became important again in the $\mathrm{XI}^{\text {th }}$ century, because of the Saracen raids in Mediterranean Sea. The main innovation was the design and construction of new mechanical dredges and crane for materials movement. About in XVII ${ }^{\text {th }}$ century, the current techniques were mainly two: breakwater jetty or the vertical wall. In fact, after the restoration of the Port of Civitavecchia, it was preferred the first method: a jetty breakwater with a concrete superstructure. In Genoa, in 1638, De Mari designed a mixed pier,

Table 2: Assessment of ports between $\mathrm{VI}^{\text {th }}$ and XVIII ${ }^{\text {th }}$ centuries.

\begin{tabular}{|c|c|c|c|c|}
\hline City & $\begin{array}{l}\text { Access } \\
\text { route }\end{array}$ & $\begin{array}{l}\text { Defensive } \\
\text { elements }\end{array}$ & $\begin{array}{l}\text { Commercial and } \\
\text { port buildings }\end{array}$ & $\begin{array}{c}\text { Commercial } \\
\text { and Port } \\
\text { spaces }\end{array}$ \\
\hline Marseille & Maritime & $\begin{array}{l}\text { Fortification, } \\
\text { walls, arsenal }\end{array}$ & $\begin{array}{c}\text { Warehouse, } \\
\text { entrepot, domaine, }\end{array}$ & $\begin{array}{l}\text { Square, piers } \\
\text { merchants } \\
\text { districts }\end{array}$ \\
\hline Genoa & Maritime & \multirow{2}{*}{$\begin{array}{l}\text { Fortifications, } \\
\text { maritime } \\
\text { walls, arsenal }\end{array}$} & $\begin{array}{c}\text { Stationes, hospitia, } \\
\text { Customhouse, } \\
\text { lodges, warehouse, } \\
\text { lighthouse }\end{array}$ & $\begin{array}{l}\text { Ripa Maris, } \\
\text { market, } \\
\text { square, piers } \\
\text { merchants } \\
\text { districts }\end{array}$ \\
\hline Naples & Maritime & & $\begin{array}{c}\text { Lodge, fondaco, } \\
\text { warehouse, } \\
\text { lighthouse }\end{array}$ & \multirow{2}{*}{$\begin{array}{l}\text { Square, piers } \\
\text { merchants } \\
\text { districts }\end{array}$} \\
\hline Venice & Maritime & $\begin{array}{l}\text { Fortification, } \\
\text { arsenal }\end{array}$ & $\begin{array}{c}\text { Fondaco, } \\
\text { warehouse, officials } \\
\text { palaces }\end{array}$ & \\
\hline Granada & $\begin{array}{c}\text { Caravan } \\
\text { routes }\end{array}$ & $\begin{array}{l}\text { Fortification, } \\
\text { castle }\end{array}$ & Alhòndiga, funduq & Suq \\
\hline Barcelona & \multirow{3}{*}{ Maritime } & \multirow{4}{*}{$\begin{array}{l}\text { Fortifications, } \\
\text { maritime } \\
\text { walls, arsenal }\end{array}$} & $\begin{array}{c}\text { Llotja, lonja, } \\
\text { pallols, lighthouse }\end{array}$ & \multirow[t]{2}{*}{ Square, piers } \\
\hline Crete & & & Warehouse & \\
\hline Acre & & & $\begin{array}{c}\text { karvansaray, hān o } \\
\text { khan, fondaco, } \\
\text { lighthouse }\end{array}$ & $\begin{array}{c}\text { Bazar, suq, } \\
\text { merchants } \\
\text { districts } \\
\end{array}$ \\
\hline Istanbul & $\begin{array}{c}\text { Maritime, } \\
\text { Caravan } \\
\text { routes }\end{array}$ & & $\begin{array}{l}\text { Bedesten, khan, } \\
\text { hān, lighthouse }\end{array}$ & $\begin{array}{c}\text { Bazar, çarçi, } \\
\text { suq, merchants } \\
\text { districts }\end{array}$ \\
\hline $\begin{array}{c}\text { Cairo, } \\
\text { Tripoli, } \\
\text { Tunis, } \\
\text { Algiers, } \\
\text { Alexandria }\end{array}$ & $\begin{array}{l}\text { Maritime, } \\
\text { Caravan } \\
\text { routes }\end{array}$ & \multirow[t]{2}{*}{$\begin{array}{l}\text { Fortifications, } \\
\text { walls }\end{array}$} & $\begin{array}{l}\text { Wakala, hān o } \\
\text { khan, funduq, } \\
\text { qaisariyya }\end{array}$ & \multirow[t]{2}{*}{$\begin{array}{l}\text { Suq, } \\
\text { merchants } \\
\text { districts }\end{array}$} \\
\hline $\begin{array}{c}\text { Damascus, } \\
\text { Aleppo, } \\
\text { Bursa } \\
\end{array}$ & $\begin{array}{l}\text { Caravan } \\
\text { routes }\end{array}$ & & $\begin{array}{c}\text { karvansaray, hān o } \\
\text { khan }\end{array}$ & \\
\hline
\end{tabular}


with a cliff foundation and a concrete structure above. Also in Venice a new pier was designed by the mathematician Zendrini: the Venetian Murazzi was a coating of stone blocks with an overall thickness of 12 meters [6].

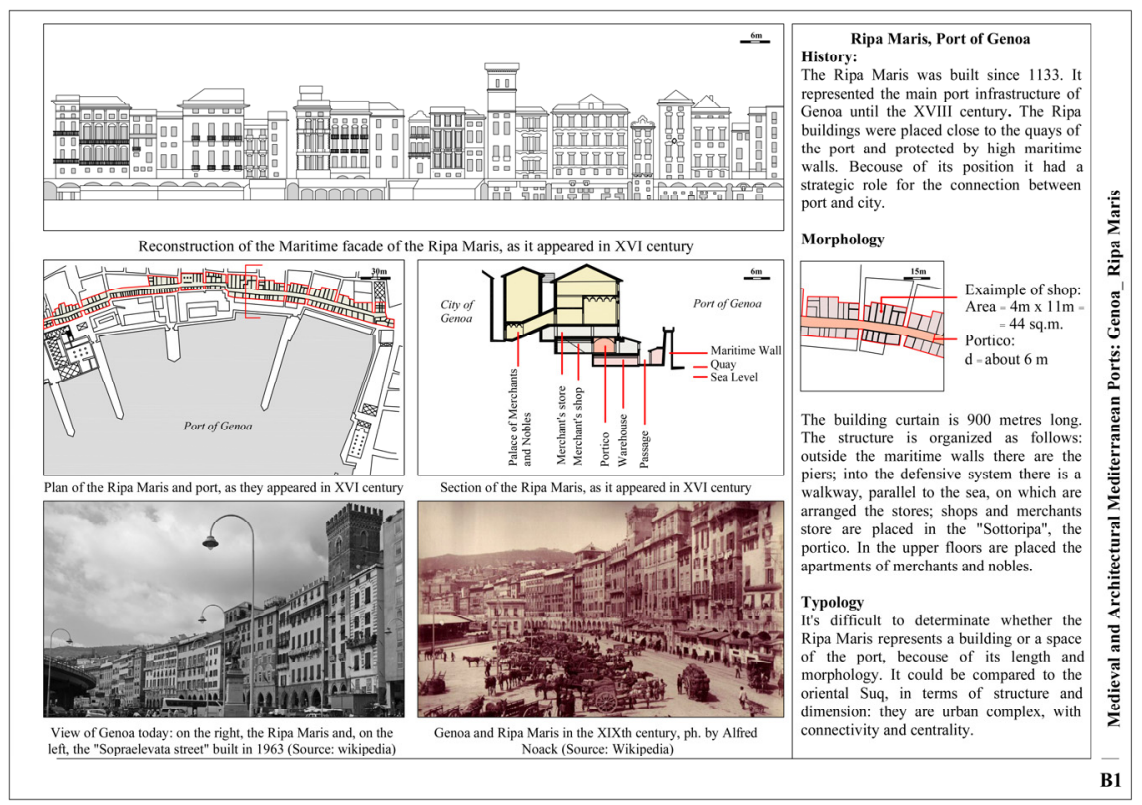

Figure 2: Assessment form of Architectural Heritage, example of the Ripa Maris.

\subsection{Modern and technological ports}

\subsubsection{Morphology}

At the end of the XVIII ${ }^{\text {th }}$ century, Mediterranean ports had obsolescence issues, such as silting of basins and decay of facilities. Furthermore, commercial traffics increased considerably, because of the opening of the Suez Canal in 1869 and for the innovations in the transport system, such as steamers and railways. In effect, piers and docks were built in series, on which many warehouses were erected. Maritime rails linked them to the railway. The first Mediterranean city to expand its port was Marseille, since the early XIX ${ }^{\text {th }}$. The inner port could no longer contain the heavy traffic of ships and then a new outer port - the Joliette - was built, starting from 1852. The new port was organized in three basins, with piers, docks and warehouses [17]. Even the port of Genoa was transformed sensibly: maritime walls were demolished, docks expanded, railways and crane took place in the port, serving the warehouses and ships [24]. In the ports of Naples new docks were realized: the Bourbon port, after a series of works, was completed in 1920 with new piers, buildings and railways, bringing its basins from 620,000 sq. m. to $2,900,000$ and its quays from 160,000 sq. m. to $1,700,000[22,25]$. The port of 
Barcelona in the early $\mathrm{XIX}^{\text {th }}$ century was expanded with new basins, piers and docks, reaching an area of more than 2,000,000 sq. m. [26].

\subsubsection{Classification of architectural heritage}

Innovation and industrialization induced morphological transformations of port areas. Firstly, docks were characterized by warehouses with a not more urban size. These large buildings were built on a "tabula rasa", such as artificial piers or quays. The Grand-Entrepot, built in Marseille in 1860, was 600 meters long and divided into 6 floors with a capacity of about 150,000 tonnes of goods (Fig. 3). The buildings were served by cranes for the loading and unloading of cargos from ships and by a railway line [17]. These typology of structures characterized also Genoa and, from 1888, they were built 12 new docks. Illustrative Album for the Exposition of Palermo of 1891 describes the port design, made by Eng. Parodi: masonry warehouses with two spans, an iron-wood coverage; iron sheds with two or three spans, 80 meters long; cranes and rails completed the system [24]. Warehouses were constructed even in Barcelona, such as Pabellon, Deposito Comercial and Tinglados, along the port front [26]. Other facilities built between the $\mathrm{XIX}^{\text {th }}$ and the $\mathrm{XX}^{\text {th }}$ century, were the maritime station and the customhouse, as in the port of Naples, Genoa and Barcelona. This typology of buildings had more architectural and urban aspect, often monumental, such as the Estacion de Mercancias or the Embarcadero de Viajeros in Barcelona, both in neoclassical style $[24,26]$.

Table 2: Assessment of ports in XIX-XX centuries.

\begin{tabular}{|c|c|c|c|c|}
\hline Port & $\begin{array}{c}\text { XVIII }^{\text {th_}} \text {-XIX } \\
\text { Centuries } \\
P=\text { Port area } \\
P / Q=\text { Piers } / \text { Quays }\end{array}$ & $\begin{array}{c}\text { XIX }^{\text {th}}-\mathbf{X X}^{\text {th }} \\
\text { Century } \\
P=\text { Port area } \\
P / Q=\text { Piers } / \text { Quays }\end{array}$ & $\begin{array}{c}\text { Port } \\
\text { Functions }\end{array}$ & $\begin{array}{c}\text { Port } \\
\text { Interventions }\end{array}$ \\
\hline Marseille & $\begin{array}{c}\mathrm{P}=220,000 \mathrm{~m}^{2} \\
\mathrm{P} / \mathrm{Q}=130,000 \mathrm{~m}^{2} \\
(\mathbf{1 7 0 0 )}\end{array}$ & $\begin{array}{c}\mathrm{P}=1,100,000 \mathrm{~m}^{2} \\
\mathrm{P} / \mathrm{Q}=960,000 \mathrm{~m}^{2} \\
(\mathbf{1 8 7 2})\end{array}$ & \multirow{4}{*}{$\begin{array}{l}\text { Industrial, } \\
\text { commercial, } \\
\text { military, } \\
\text { passenger }\end{array}$} & \multirow{4}{*}{$\begin{array}{c}\text { Docks, new } \\
\text { port, piers and } \\
\text { quays, maritime } \\
\text { railroad, } \\
\text { warehouse, } \\
\text { crane, maritime } \\
\text { station, } \\
\text { customhouse, } \\
\text { fisherman } \\
\text { district. }\end{array}$} \\
\hline Genoa & $\begin{array}{c}\mathrm{P}=1,000,000 \mathrm{~m}^{2} \\
\mathrm{P} / \mathrm{Q}=230,000 \mathrm{~m}^{2} \\
\mathbf{( \mathbf { 1 8 5 4 } )}\end{array}$ & $\begin{array}{c}\mathrm{P}=1,300,000 \mathrm{~m}^{2} \\
\mathrm{P} / \mathrm{Q}=844,000 \mathrm{~m}^{2} \\
(\mathbf{1 9 0 2})\end{array}$ & & \\
\hline Naples & $\begin{array}{c}\mathrm{P}=620,000 \mathrm{~m}^{2} \\
\mathrm{P} / \mathrm{Q}=160,000 \mathrm{~m}^{2} \\
(\mathbf{1 8 0 0 )}\end{array}$ & $\begin{array}{c}\mathrm{P}=2,900,000 \mathrm{~m}^{2} \\
\mathrm{P} / \mathrm{Q}=1,700,000 \mathrm{~m}^{2} \\
\mathbf{( 1 9 2 0 )}\end{array}$ & & \\
\hline Barcelona & $\begin{array}{c}\mathrm{P}=1,360,000 \mathrm{~m}^{2} \\
\mathrm{P} / \mathrm{Q}=160,000 \mathrm{~m}^{2} \\
(\mathbf{1 8 7 0 )}\end{array}$ & $\begin{array}{c}\mathrm{P}=2,560,000 \mathrm{~m}^{2} \\
\mathrm{P} / \mathrm{Q}=1,280,000 \mathrm{~m}^{2} \\
\mathbf{( 1 9 1 0 )}\end{array}$ & & \\
\hline
\end{tabular}

\subsubsection{Techniques construction of piers and quays}

The expansion of modern ports led to the construction of dams, piers and docks. The current techniques were mainly two: the jetties breakwaters and the prefabricated blocks. The first was used in the late $\mathrm{XIX}^{\text {th }}$ century, both in Barcelona and Genoa, for the extension of the outer pier. While in Barcelona the 
Dique of the Este was a classic pier with scattered stones and upper wall [26], in Genoa a new technique was experimented. The West pier, called De Ferrari Galliera, was prolonged to create the new outer basin. The works were built in three construction phases: firstly, the foundation stone; secondly, the substructure with artificial blocks; at last, the defensive wall and the moorings. The innovation was in the second step. In fact, while in the ports of Livorno and Marseille, the jet of the stones was random, in Genoa it was realized with a regular masonry. The great resistance shown by the dam in the following years led to the adoption of the technique in other ports [24]. Finally, a prefabricated dam was realized in Naples for the piers called Duca degli Abruzzi and Thaon de Ravel [25].

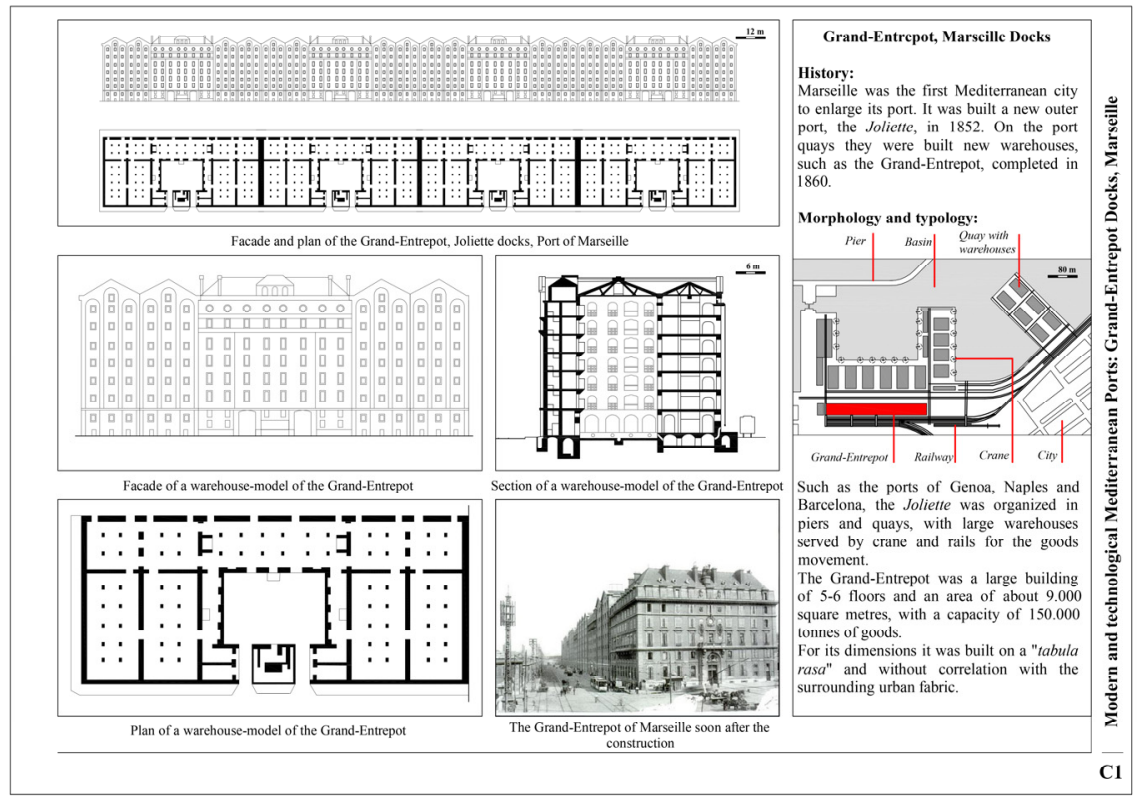

Figure 3: Assessment form of Modern Heritage, example of the Gran-Entrepot.

\section{Discussion of results and conclusions}

The contribution has discussed historical and morphological evolution of some Mediterranean ports. Particularly, it emerges that ancient ports of Rome had many similarities with the modern ports. In fact, they were real infrastructures often unrelated and independent from the urban centre. In other cases, such as Carthage, Leptis Magna or Alexandria, instead, port-city system had a synergic relationship. Even for technological innovations, Roman ports and constructions could be compared to $\mathrm{XIX}^{\text {th }}$-century ports, mainly for enlargement, long piers and large basins. From the Middle Ages, ports and cities joined into a unique system, represented by the emporium. In this era, port facilities crossed the urban boundaries, leaving port quays and placing into the urban fabric. Historically, three 
categories have been identified: ancient, medieval- architectural and modern heritage. Typologically, instead, different kind of heritage can be recognized. Archaeological heritage can be remains of warehouses, squares, palaces, submerged piers and quays, among the others. The second historical category can count fortifications, urban and suburban buildings, architectural complex, districts and waterfront, arsenals, piers and docks. Finally, modern heritage, often built in mixed techniques construction, can be warehouses, customhouses, captaincies, maritime stations. According to the Charters of Venice and Krakow, the preservation cannot be limited to a single monument, but it even concerns large historical areas or waterfronts, which must be protected, maintaining their authenticity and identity. One of the goals of this research is the definition of a methodological assessment of risks of the port heritage, through the implementation of specific forms of territorial hazard and heritage vulnerability. The hazard factor is linked to the aggressiveness of the context, such as industrial and anthropic effects or innovation and dynamism of ports. Vulnerability, instead, is a factor related to the state of conservation and intrinsic characteristics of historical heritage, and expresses the level of exposure to the hazard. In this contribution, the morphological assessment aims to the understanding of the causes and dynamics of transformations and changes of the port areas and, then, is tied to hazard concept. Future works will focus on present effects and pressures of the port activities. The typological classification and assessment of heritage is functional to the preparation of specific forms for vulnerability analyses. In fact, they are different for each typology of building or space. Subsequently, the analysis will lead to the definition of guidelines and strategies for the conservation and enhancement of the port.

\section{References}

[1] Hoyle, B.S., Pinder, D. A., Husain, S. M., Aree portuali e trasformazioni urbane: le dimensioni internazionali della ristrutturazione del waterfront, Mursia, Milano, Italy, 1994.

[2] Gras, P., Storia dei porti - Declino e rinascita delle città portuali - 19402010, Odoya, Città di Castello (Pg), Italy, 2013.

[3] De Fino, M., Fatiguso, F., De Tommasi, G., Assessment and development of historical ports, in Stylios, C., Floqi, T., Marinski, J., Damiani, L. (Eds.), Sustainable Development of Sea-Corridors and Coastal Waters, Springer, 2015.

[4] Accardo, G., Giani, E., Giovagnoli, A., The risk map of Italian Cultural Heritage, Journal of architectural conservation n. 2, pp. 1-57, 2003.

[5] Badami, A., Carta del Rischio per $i$ waterfront in area storica. Modelli di rigenerazione urbana per le città costiere in Sicilia, Portusplus n. 1, 2010.

[6] Franco, L., Storia dell'Ingegneria marittima in Italia, Atti del $1^{\circ}$ Convegno su "Storia dell'Ingegneria", AISI, Cuzzolin, Napoli, 2006.

[7] Anser - Anciennes Routes Maritimes Mediterraneennes, I porti antichi del Lazio, Programme Interreg III B Medocc, Regione Lazio. 
[8] Franco, L, Ancient Mediterranean harbours: a heritage to preserve, Ocean \& Coastal Management, Vol. 30, pp. 115-151, 1996.

[9] Simoncini, G., Sopra i porti di mare: Vol. II, Olschki, Firenze, 1993.

[10] Pucci, S. et al., Environment-human relationships in historical times: The balance between urban development and natural forces at Leptis Magna (Libya), Quaternary International 242, pp. 171-184, 2011.

[11] Soprintendenza Speciale per i Beni Archeologici di Roma, Porticus Aemilia Project - Recupero del patrimonio storico urbano contemporaneo.

[12] Portus - Ministero per i Beni e le Attività Culturali, Soprintendenza per i beni archeologici di Ostia.

[13] Vitruvius, M., P., De Architectura, Kappa, Roma, 2002.

[14] Salvatori, M., Il porto dell'antica Puteoli: evoluzione dell'ingegneria marittima in età romana, atti del $2^{\circ}$ Convegno Nazionale, Storia dell'ingegneria, Napoli, pp. 431-440, 2008.

[15] Simoncini, G., Sopra i porti di mare: Vol. I, Olschki, Firenze, 1993.

[16] Kesten, A., The Old City of Acre. Re-examination report 1993, The Old Acre Development Company, 1993.

[17] Fallanca De Blasio, C., Nazer Eslami, A., Luoghi dello scambio e città del Mediterraneo: storie, culture, progetti, Liriti, Reggio Calabria, 2003.

[18] Colletta, T., Città portuali del Mediterraneo, Franco Angeli, Milano, 2012.

[19] Concina, E., Fondaci: architettura, arte e mercatura tra Levante, Venezia e Alemagna, Marsilio, Venezia, 1997.

[20] Poleggi, E., Città portuali del Mediterraneo: storia e archeologia - Atti del Convegno Internazionale di Genova 1985, Sagep, Genova, 1989.

[21] Borruey, R., Marseille - Ville et Port, Editions Paranthèses, Marseille, 1992.

[22] De Seta, C., Le città nella storia d'Italia - Napoli, Laterza, Bari, 1991.

[23] Concina, E., L'Arsenale della Repubblica di Venezia: tecniche ed illustrazioni dal Medioevo all'età moderna, Electa, Milano, 1988.

[24] Ing. Capo P. Giaccone, Il porto di Genova - Album illustrativo per l'Esposizione Nazionale di Palermo, Genova, 1891.

[25] Benassai, E., L'evoluzione delle opere di difesa per il porto di Napoli, Il giornale dell'Ingegnere, n. 2, 2014.

[26] Archivio Historico, Port de la Ciutada, Barcelona: De la Memoria sobre el estado y adelanto de las obras del puerto de Barcelona durante los años: 1881, 1893, 1907-1910, 1911-1915, 1926-1929, 1953-1957. 